\title{
ANALYSIS OF MARKETING EFFECTS OF IMPLEMENTING ON-LINE AIRBNB PLATFORM IN REAL ESTATE MARKET AT BALKANS AS A TOURISM REGION
}

\author{
Danilo Grbović 1 \\ Branislav Radnović ${ }^{2}$ \\ Željana Grbović ${ }^{3}$ \\ Diona Đurđević ${ }^{4}$
}

DOI: https://doi.org/10.31410/tmt.2019.341

\begin{abstract}
The base hypothesis is that implementation of the Airbnb on-line platform at the Balkans' real estate market, contributes to Balkans tourism region, with various positive marketing effects. The conducted research has covered the analysis of renting property for the purpose of tourism in the Balkans in some of the major cities and most attractive tourist destinations - Ljubljana, Bled, Zagreb, Dubrovnik, Belgrade, Novi Sad, Sarajevo, Budva, Podgorica, Skopje and Ohrid. By analysing results of the research the base hypothesis is confirmed, with bringing to light following marketing effects: increase in the number of accommodation units registered on-line, extended number of accommodation facilities, growth in number of stays per night, lengthened time spam of a stay, expanded occupancy of accommodation facilities, growth of entrepreneurship of local population, tourism revenue growth. The conclusion is that implementation of such on-line platforms as the Airbnb is of extreme importance for the Balkans tourism region.
\end{abstract}

Keywords: Airbnb Platform, Marketing Effects, Real Estate Market, Tourism, the Balkans.

\section{INTRODUCTION}

$\mathrm{D}$ evelopment of web platforms in the field of tourism is one of the major breakthroughs in this industry. A good idea represents the core of a great marketing campaign (Radnović, 2019). Their contribution and impact on the way renting is done as well as price forming has greatly changed traditional ways of travel and booking accommodation. Apart from quality tourism services, which are implied in the modern market game, a successful marketing strategy is crucial for the development of tourism. Nowadays, a successful marketing strategy necessarily includes new digital media, primarily the Internet and its services (Radnović, 2019).

Although the Airbnb platform is around for just a decade, since 2008 to be precise, it succeeded to find its way through the market and to come on top of other similar applications. A booking web application is first launched in 1996 and rapidly conquered the market and united worldwide hotel offer at one place. These two applications are not to be compared nor are they competitive due to different target groups and types of accommodation that they have in their offers. The way from the idea to its realization took some time but the speed and level of its develop-

Educons University, Faculty of Business Economy, Vojvode Putnika 87, Novi Sad - Sremska Kamenica, Serbia

2 Educons University, Faculty of Business Economy, Vojvode Putnika 87, Novi Sad - Sremska Kamenica, Serbia

3 University of Novi Sad, BioSense Institute, Zorana Đinđića 1, Novi Sad, Serbia

4 Educons University, Faculty of Business Economy, Vojvode Putnika 87, Novi Sad - Sremska Kamenica, Serbia 
ment could hardly be foreseen by anyone (Guttentag, 2015). Apart from the very influence on the conventional ways in tourism, the real estate renting market, forming a price of an accommodation, through encouraging such practical application, can be distinguished entrepreneurial spirit. Such way of practice in tourism via internet, became essential when bookings around the world are in question (Zervas, 2017; Guttentag, 2017; Similarweb (2019, November 12, retrieved from https://www.similarweb.com/website/airbnb.com).

The Airbnb platform is accessible via a computer or a mobile phone. It connects landlords and those who desire to hire property for the purpose of tourism.

There is a wide range of accommodation types it offers, from standard private room within a house or an apartment, studios, one room apartments or multiple room apartments, to entire houses available as a whole.

Booking a reservation is done in the same way as before, whether it is done through an agency or other websites.

Listing a property for renting is done by creating a profile at which are presented photographs of the real estate together with detailed description of the premises that are to be rented.

Searching the website or the application is done based on several criteria: by the type of the accommodation (entire place, private room or shared room), date, location and price per night. Creating a profile, except for landlords goes also for tourists who wish to hire some property in this way, the reason is to make personal information transparent, while the data regarding payment is regulated by legislation on data protection.

The description of the real estate that is being rented is, more often than not, very detailed in order to attract as many tourists as possible. Available information about a property is: capacity, type of accommodation, rules that are set by an owner or a landlord empowered to run the real estate and similar. Price per night can be fixed, set by an Airbnb host, or to be adaptive to a season or a change in demand for the given period of time.

What makes the Airbnb application so popular is a close contact with their hosts through forming communities of the Airbnb hosts in the cities, together with advice on how to make a property more appealing and consequently earn more.

The most significant influence on attractiveness of some real estate listed for renting, play public sharing of mutual experience, which are valuable as being informative, for an owner to know what kind of a tourist they are to welcome as well as for a tourist to be informed what to expect regarding accommodation and a host, during their stay in the property of the choice (Jøsang, 2007).

The way the company profits is a tax on connecting a host and a tourist, e.g., in a form of a cut as a certain percentage in a booking price or the cost of the advertised event.

This application offers several measures of verification in order to build trust and protect safety of both end users, and insurance covering the period of stay, and also refund of the paid price decreased by the booking tax if the cancellation is made within assigned time frame set by the host in the profile. 
Constant improvement and development of this application bring new options such as instant booking, e.g. a reservation that does not need a confirmation of the host. After the booking is done this way there is a deadline of $24 \mathrm{~h}$ within which both sides have to confirm the reservation.

Excluding close communication in a shape of advice on how to improve a property that is being rented, there is an incentive for the hosts in a way of proclaiming one a "superhost". This status distinguishes certain accommodation units based on quality they provide and are good examples of successful business activities via this application. To gain such a status, it is necessary to realise sufficient number of bookings, remarkable experience impressions from the previous tourists that have been hosted in the property, and marks of the property itself following criteria of tidiness, cleanness, facilities etc., including behaviour and readiness to act of a host.

Except for basic offer of individual accommodation units, the Airbnb application also offers conducted cooperation with several tourist agencies that are into corporate travel (Griswold, 2016). Also, there is a project to build a real estate complex specially planed for renting through the Airbnb application (Quackenbush, 2018).

The assortment of the secondary offer of this company is rather wide, thus through this application is possible to book restaurants or some activities like organized outings, touristic tours through out a city with a local guide, attending cooking courses or gaining some skills and also getting to know a city through its culture and preparation of a traditional meal or learning a local dance.

Table 1. Available data for the Airbnb platform for the period of 2010-2018

\begin{tabular}{|c|c|}
\hline Year & Number of realised registered reservations in millions \\
\hline 2010 & 0.14 \\
\hline 2011 & 0.8 \\
\hline 2012 & 3 \\
\hline 2013 & 6 \\
\hline 2014 & 16 \\
\hline 2015 & 40 \\
\hline 2016 & 80 \\
\hline 2017 & 115 \\
\hline 2018 & 164 \\
\hline
\end{tabular}

Source: http://insideairbnb.com/ (website data on 16.10.2019.)

Data from Table 1 shows exponential growth of number of realized reservations in millions for a period from 2010 till 2018 (Molla, 2017; Team, 2018). This number of realized reservations indicates that the Airbnb had at its disposal 5 million accommodation units in 2018 (Airbnb, 2018). Another interesting fact in relation to paradoxical success of this company is that at every moment, as it is shown above, this company has at its disposal extremely large number of properties to rent, taking a percentage and booking taxes from them and none of them is owned by it. The available data on the capacity from 2018, proves that it exceeds even the most successful hotel companies around the world (Hartmans, 2017).

Permanently marketing research of customers are very important (2019, October 9, retrieved from https://press.airbnb.com/fast-facts/). Current data available at official website of the Airbnb application (Radnović, 2015) state that the Airbnb offers more than 7 million accommodation units, in more than 100.000 cities, in 190 countries worldwide. More than 500 million of tourists 
have booked their accommodation by this application. Novelties such as the activities are still in the development stage and at the moment there are 40 thousand listed in more than 1.000 cities. Current data on the evaluation of the capital of this company points to a figure of $\$ 60$ billion.

\section{A STARTING BASE OF THE RESEARCH}

By applying desk research method and using random sampling for analysing marketing effects of the on-line AirBnB platform, the following cities at the Balkans are selected: Ljubljana, Bled, Zagreb, Dubrovnik, Belgrade, Novi Sad, Sarajevo, Podgorica, Budva, Skopje and Ohrid. The sample includes the capital cities of the following Balkan countries: Slovenia, Croatia, Serbia, Bosnia and Herzegovina, Montenegro, Macedonia; secondary biggest cities and/or attractive tourist destinations of the selected Balkan countries.

The aim is that by analysing current number of active accommodation units registered at the Arbnb platform, namely the average monthly earnings, price per night, occupancy in percentage and in days, as well as other significant statistic parameters, in all mentioned cities, to get an insight into marketing effects of the applying the on-line Airbnb platform to a market of the real estate renting to tourists in the Balkan as a tourism region.

In this analysis, as a base hypothesis is taken a presumption that by using the tourism Airbnb platform in the real estate market at the Balkans brings various positive effects to this region. The period in which the research is conducted is from the mid-September till the end of November 2019.

\section{PRESENTATION AND ANALYSIS OF THE COLLECTED DATA}

\subsection{Slovenia: Ljubljana and Bled}

Based on available data from the sources relating to Slovenia, using random sampling method, two cities are chosen for the analysis: The capital city- Ljubljana (2019, Sept 22, retrieved from https://www.airdna.co/vacation-rental-data/app/si/default/ljubljana/overview) and attractive tourist location- Bled. In Ljubljana are 2.472 active accommodation units that are registered at online tourism platforms, out of which $91 \%$ at the Airbnb platform. $76 \%$ are properties that are entirely available - illustrated in purple on the map bellow (see Figure 1). Almost a half of all available accommodation units are one room apartments. The average price per night is $€ 72$, average occupancy is about $74 \%$ per year, i.e. 270 days per year, which results in average monthly earning of $€ 1.185$.

According to available data from the source (2019, September 22, retrieved from https://www. airdna.co/vacation-rental-data/app/si/default/ljubljana/overview) in the city of Bled are 882 active accommodation units that are listed at online tourism platforms, out of which are $83 \%$ at the Airbnb platform. Accommodation units that are let as entire places dominate with $81 \%$ illustrated in purple on a map above (see Figure 2). The average price per night is $€ 100$, while average monthly earnings are $€ 1.437$.

Viewing spatial distribution of accommodation units leads to the conclusion that in the capital -Ljubljana the biggest concentration is in the centre of the city, while in reputedly attractive touristic places like Bled, distribution a bit broader. 


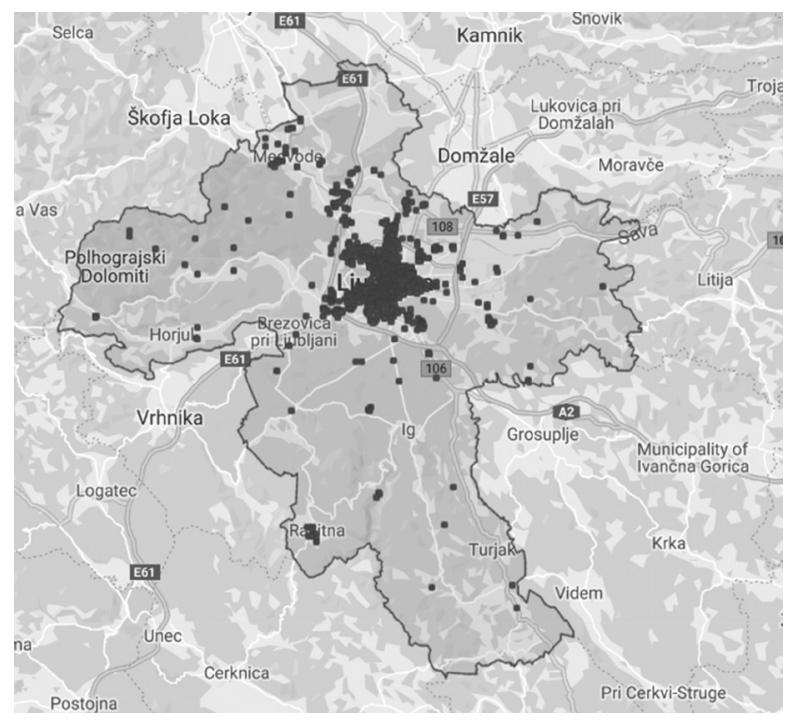

Figure 1. Spatial representation of accommodation unit distribution in the city area of Ljubljana

Source: retrieved from https://www.airdna.co/vacation-rental-data/app/si/default/ljubljana/overview (2019, September 22)

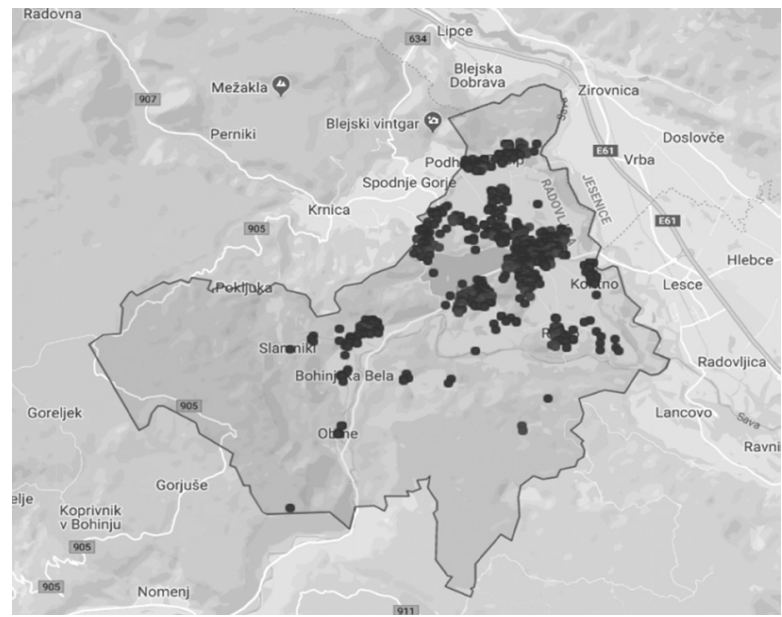

Figure 2. Spatial representation of accommodation unit distribution in the city area of Bled Source: retrieved from https://www.airdna.co/vacation-rental-data/app/si/default/bled/overview (2019, September 23)

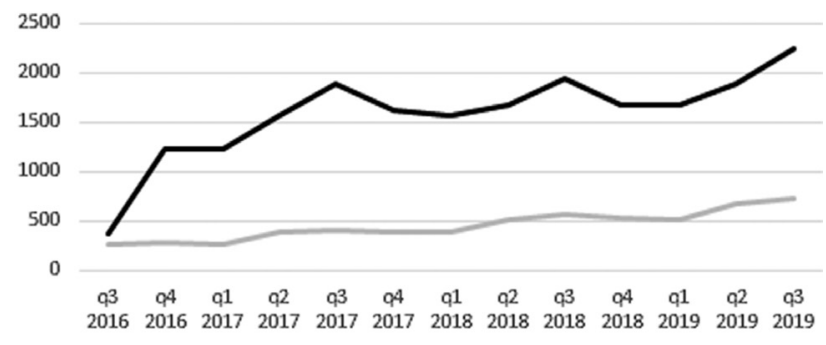

— Lijubjana —Bled

Figure 3. Illustration of the number of registered listings at the Airbnb platform in Ljubljana and Bled by annual quarters for the period of 2016-2019

Sources: retrieved from

https://www.airdna.co/vacation-rental-data/app/si/default/ljubljana/overview (2019, November 15), https://www.airdna.co/vacation-rental-data/app/si/default/bled/overview (2019, September 27) 
On the graph above (see Figure 3) is clearly notable increase in the third quarter over the years, neglecting the first one in the analysis (in 2016), which refers to July, August and September the peak of the tourist season.

\subsection{Croatia: Zagreb and Dubrovnik}

In analysing marketing effects of using on-line Airbnb platform in Croatia are chosen the capital city - Zagreb (2019, October 5, retrieved from https://www.airdna.co/vacation-rental-data/app/ $\mathrm{hr} /$ default/zagreb/overview) and one of the most attractive tourist destinations - Dubrovnik (2019, October 6, retrieved from https://www.airdna.co/vacation-rental-data/app/hr/default/dubrovnik/ overview). There are 4.091 registered active accommodation units in Zagreb, at online tourism platforms, out of which even $87 \%$ are at the Airbnb platform. $90 \%$ make for properties that are rented as entire places - illustrated in purple on the map bellow (see Figure 4). Almost a half are one room apartments, and a quarter respectively goes to studios and two room apartments. Average price per night is $€ 48$, with average occupancy of $62 \%$ a year, i.e., 222 days, resulting in average monthly earnings of $€ 673$.

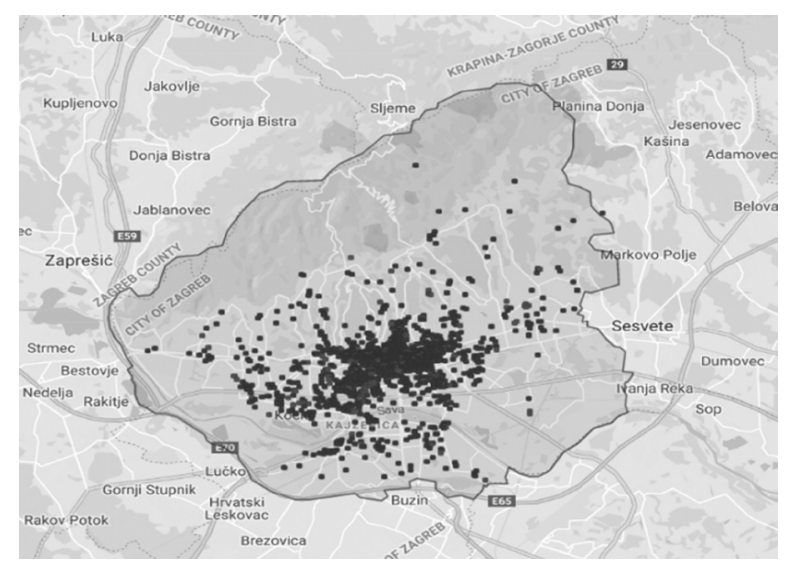

Figure 4. Spatial representation of accommodation unit distribution in the city area of Zagreb

Source: retrieved from https://www.airdna.co/vacation-rental-data/app/hr/default/zagreb/overview (2019, October 5)

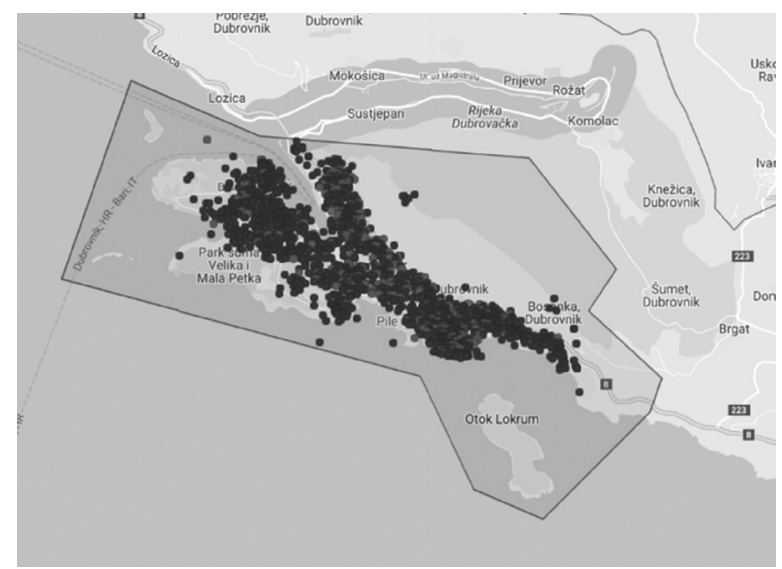

Figure 5. Spatial representation of accommodation unit distribution in the city area of Dubrovnik

Source: retrieved from

https://www.airdna.co/vacation-rental-data/app/hr/default/dubrovnik/overview, (2019, October 6) 
In the city of Dubrovnik are 7.349 active accommodation units registered at online tourism platforms, out of which $63 \%$ are at the Airbnb platform, and $86 \%$ of those are listed entire places - illustrated in purple on the map above (see Figure 5). Nearly half are one room apartments, and a quarter are two room apartments while one fifth goes to studios. The average price per night is $€ 90$, average occupancy is even $77 \%$, that is to say 281 days per year, which comes to monthly earnings of $€ 1.549$.

In Croatia likewise, in the capital city the highest concentration of the accommodation units is within the centre of Zagreb, while attractive tourist destination - Dubrovnik, with its islands, has much broader distribution, basically due to a fact that the Tourism is one of the main industries the local population works in.

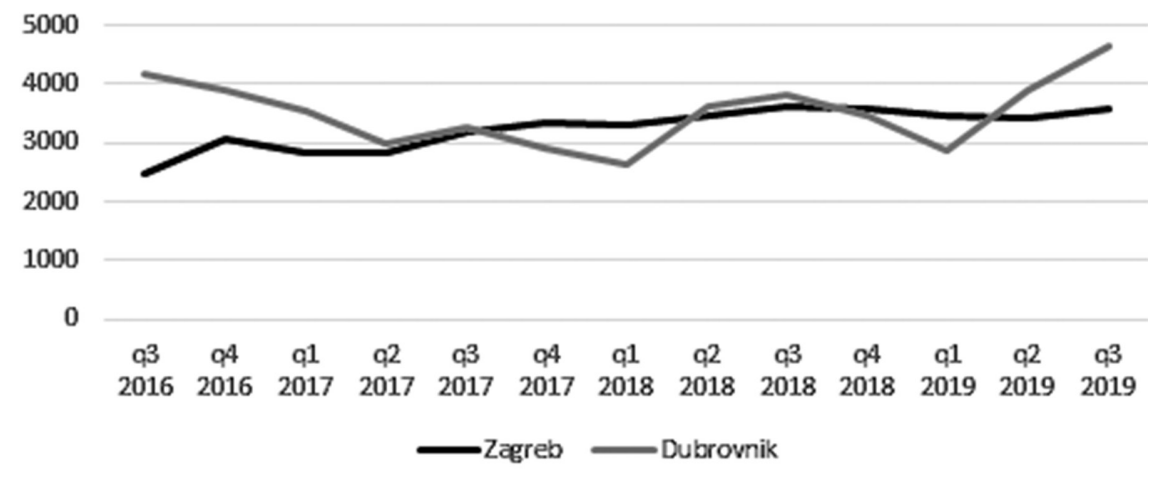

Figure 6. Illustration of the registered listings at the Airbnb platform in Zagreb and

Dubrovnik by annual quarters in a period of 2016-2019

Sources: retrieved from

https://www.airdna.co/vacation-rental-data/app/hr/default/zagreb/overview (2019, October 5),

https://www.airdna.co/vacation-rental-data/app/hr/default/dubrovnik/overview, (2019, October 10)

From the graph above (Figure 6) is clear that when Zagreb is in question there are no significant oscillations in the number of registered listings by annual quarters, except that is noticeable slight increase in the number of listed property for renting which is enhanced by growing popularity and at the same manner marketing effects of introducing the Airbnb platform, while Dubrovnik has deeper falls in the first quarter of a year - first three months of a year, which makes sense, considering that the city is at the coast, so the winter time attracts far less tourists. Furthermore, the analysis brings to a conclusion that such dynamics of growth and downfall in quantity of registered and active accommodation units in coastal cities indicates a certain number of properties that is normally used by local population to reside in, which however, are being let during tourism season.

\subsection{Serbia: Belgrade and Novi Sad}

For the purpose of the analysis regarding the impact of the on-line Airbnb platform in Serbia, the research covered two cities: Belgrade (2019, October 16, https://www.airdna.co/vacation-rental-data/app/rs/default/belgrade/overview), the capital city and Novi Sad, chosen as the second in size and as one of the most attractive tourist destinations in Serbia (2019, October 17, retrieved from https:/www.airdna.co/vacation-rental-data/app/rs/default/novi-sad/overview). In Belgrade are 5.564 active accommodation units that are registered at online tourism platforms, $92 \%$ of them are at the Airbnb platform. The type of the accommodation that dominates the offer are the properties that are let as entire places - $88 \%$ out of total - illustrated in purple on the map bellow (see Figure 7). Exactly one half make for one room apartments. The average price per night is $€ 34$, with average capacity of $56 \%$ per year, that is to say 204 days annually, making on average $€ 446$ a month. 


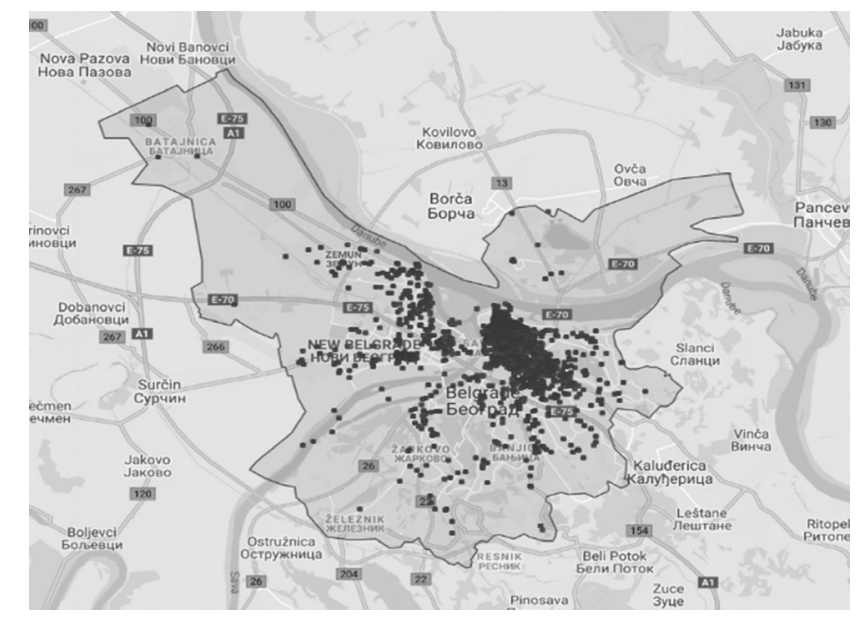

Figure 7 Spatial representation of accommodation unit distribution in the city area of Belgrade

Source: retrieved from https://www.airdna.co/vacation-rental-data/app/rs/default/belgrade/overview (2019, October 16)

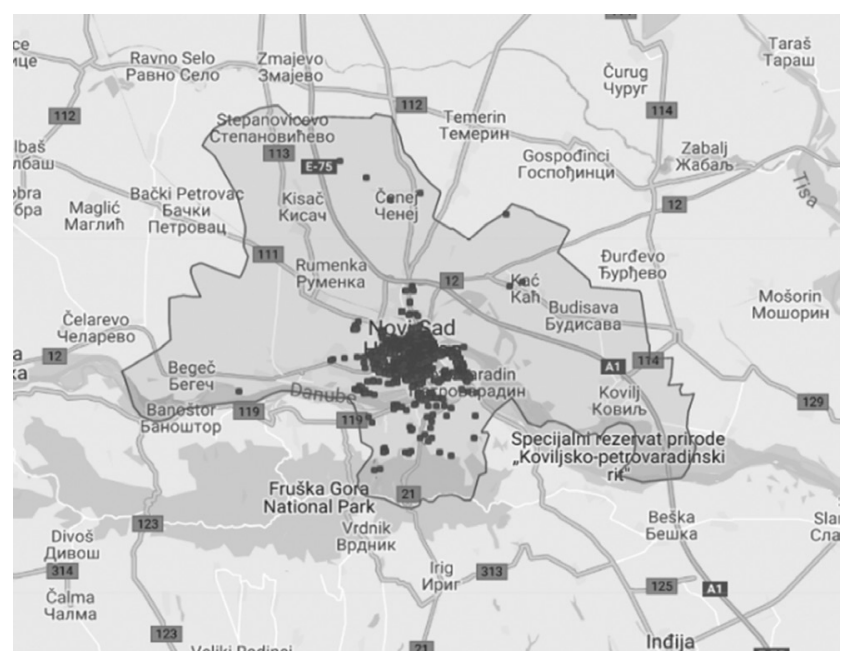

Figure 8. Spatial representation of accommodation unit distribution in the city area of Novi Sad

Source: retrieved from

https://www.airdna.co/vacation-rental-data/app/rs/default/novi-sad/overview, (2019, October 17)

In Novi Sad, there are 1.822 active accommodation units that are registered at online tourism platforms, out of which $97 \%$ are registered at the Airbnb platform. 91\% is accommodation that is rented as entire place- illustrated in purple on the map above (see Figure 8). Near one half are one room apartments or studios while bigger apartments are scarce to find.

Spatial representation of accommodation unit distribution of the given tourist destinations in Serbia (see Figure 7 and 8 ) is fairly similar, unlike the two previous cases (Slovenia and Croatia), since in this case the two cities are alike in a way that they function (business, educational, cultural, sport centres). The biggest concentration of the registered accommodation units in both cities is the very centre, nevertheless, there is a notable tendency of growth and broadening the distribution in Belgrade. 


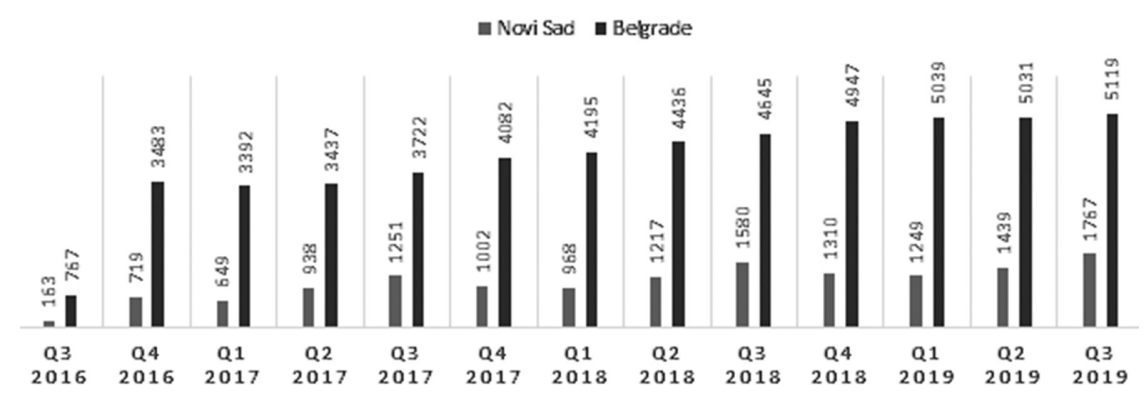

Figure 9. Illustration of the registered listings at the Airbnb platform in Belgrade and Novi Sad by annual quarters in a period of 2016-2019

Sources: retrieved from

https://www.airdna.co/vacation-rental-data/app/rs/default/belgrade/overview (2019, October 16.), https://www.airdna.co/vacation-rental-data/app/rs/default/novi-sad/overview, (2019, October 21)

Investigating data of the third quarter, e.g. information for the months of July-August-September, for the given period in the graph (see Figure 9), it is noticeable a significant increase in the number of listings. The results of this statistics are explainable by the fact that apartments are chiefly let to students and high school pupils, thus the flats that are normally rented to students during a school and an academic year, are let via on-line Airbnb platform or some similar, during summer months. Apart from fluctuation in number of registered listings, there is a more significant fluctuation in a price, thus, in October that is the fourth quarter the average one is $€ 26$, in the third quarter - in July is $€ 48$ on average, which makes the mean price per night of $€ 30$, in Novi Sad (2019, October 17, retrieved from https://www.airdna.co/vacation-rental-data/app/rs/default/novi-sad/overview). Average occupancy is $45 \%$, or 164 days annually, which makes average earnings of $€ 318$ per month.

\subsection{Bosnia and Herzegovina: Sarajevo and Mostar}

For analysing results of the marketing effect of the AirBnB platform in Bosnia and Herzegovina, two cities are taken: Sarajevo and Mostar. It is established that there are 2.877 active accommodation units that are registered at online tourism platforms, out of which 93\% at the Airbnb platform. $87 \% 91 \%$ is accommodation that is rented as entire place- illustrated in purple on the map bellow (see Figure 10). Nearly half of the total number of the available accommodation units are one room apartments and one third two room apartments (2019, October 26, retrieved from https://www.airdna.co/vacation-rental-data/app/ba/default/ sarajevo/overview). The average price per night in Sarajevo is €36. And average occupancy is $42 \%$, while the earnings accumulate to $€ 347$ a month.

According to website available data (2019, October 27, retrieved from https://www.airdna.co/ vacation-rental-data/app/ba/default/mostar/overview) in Mostar are 1.123 active real estates that are let and that are registered at online tourism platforms. At the Airbnb platform is registered $94 \%$ out of total number of active profiles. $70 \%$ is accommodation that is rented as entire place - illustrated in purple on the map above (see Figure 11). Percentage of one room and two room apartments is rather even, $37 \%$ and $33 \%$ respectively. The average price per night is the same as in Sarajevo, €36, which is rather interesting piece of information. Average occupancy is $42 \%$, and average earnings are $€ 378$. Spatial distribution of accommodation units in Sarajevo is similar to other analysed cities, highly concentrated properties for renting in the city centre with a tendency to extend wider, while in Mostar can be distinguished two regions with the highest percentage of the accommodation units available to tourists via the Airbnb platform. 


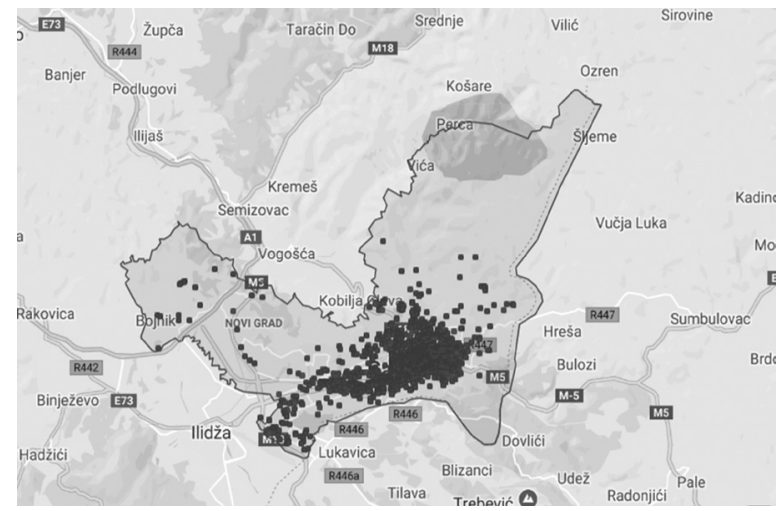

Figure 10. Spatial representation of accommodation unit distribution in the city area of Sarajevo

Source: retrieved from

https://www.airdna.co/vacation-rental-data/app/ba/default/sarajevo/overview (2019, October 26),

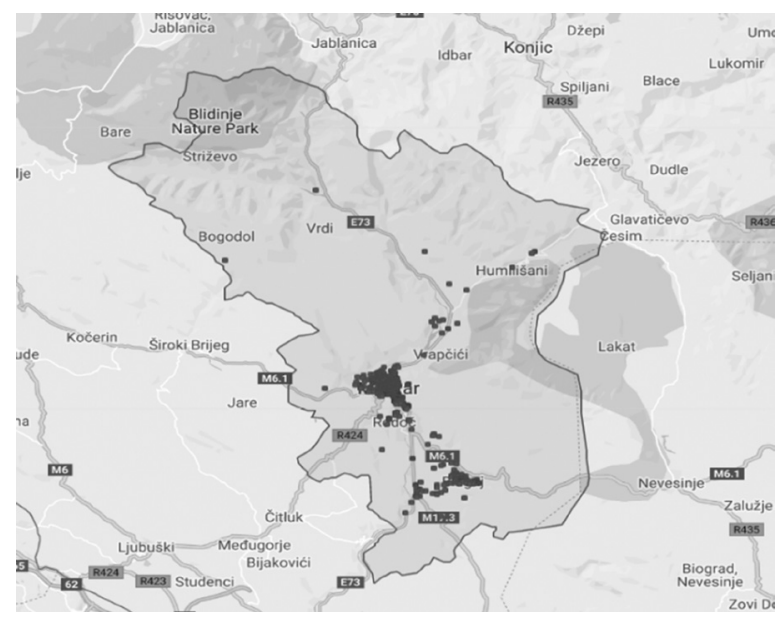

Figure 11. Spatial representation of accommodation unit distribution in the city area of Mostar

Source: retrieved from

https://www.airdna.co/vacation-rental-data/app/ba/default/mostar/overview (2019, October 27)

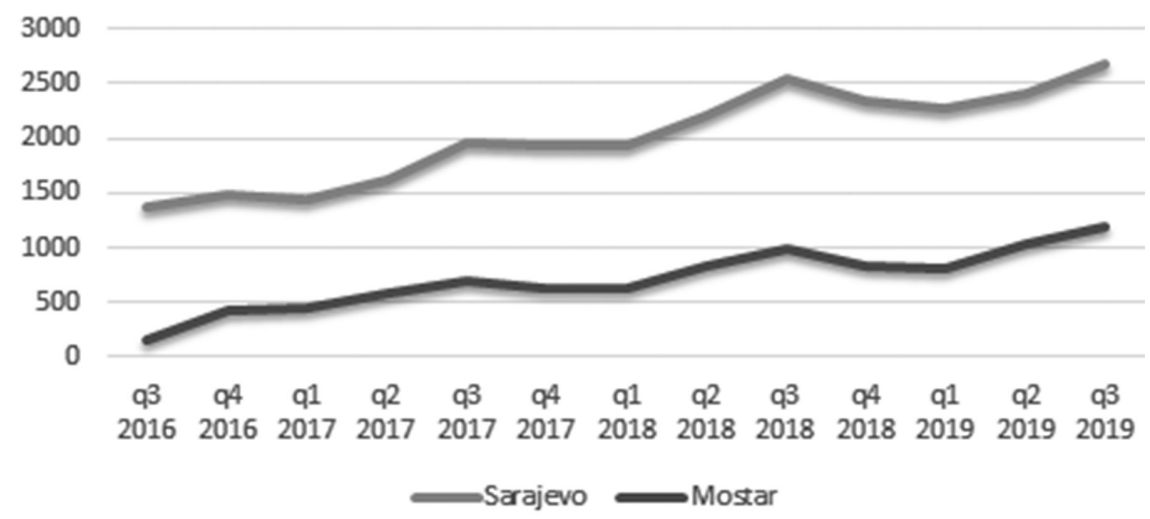

Figure 12. Illustration of the registered listings at the Airbnb platform in Sarajevo and Mostar by annual quarters in a period of 2016-2019

Sources: retrieved from

https://www.airdna.co/vacation-rental-data/app/ba/default/sarajevo/overview (2019, October 26), https://www.airdna.co/vacation-rental-data/app/ba/default/mostar/overview (2019, October 31) 
In the graph above (see Figure 12) is clearly visible an increase a year after year, observing that there is a significant growth between the first and the third quarter, followed consistently by a slight decrease or stagnation in the fourth quarter.

\subsection{Montenegro: Podgorica and Budva}

Analysing marketing impact of applying the AirBnB platform on the state of Montenegro, as a sample are taken the capital - Podgorica and Budva as one of the major tourists centres in Montenegro but also at the Balkans and Europe.

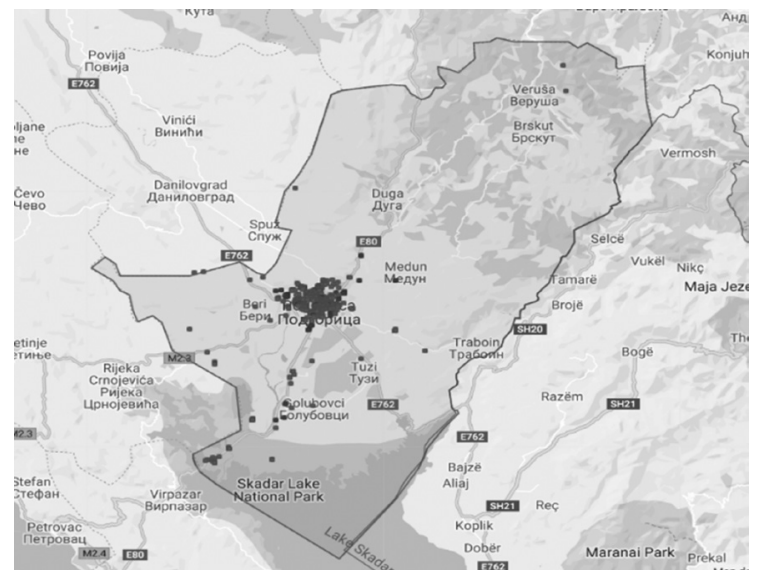

Figure 13. Spatial representation of accommodation unit distribution in the city area of Podgorica

Source: retrieved from

https:/www.airdna.co/vacation-rental-data/app/me/default/podgorica/overview (2019, November 7)

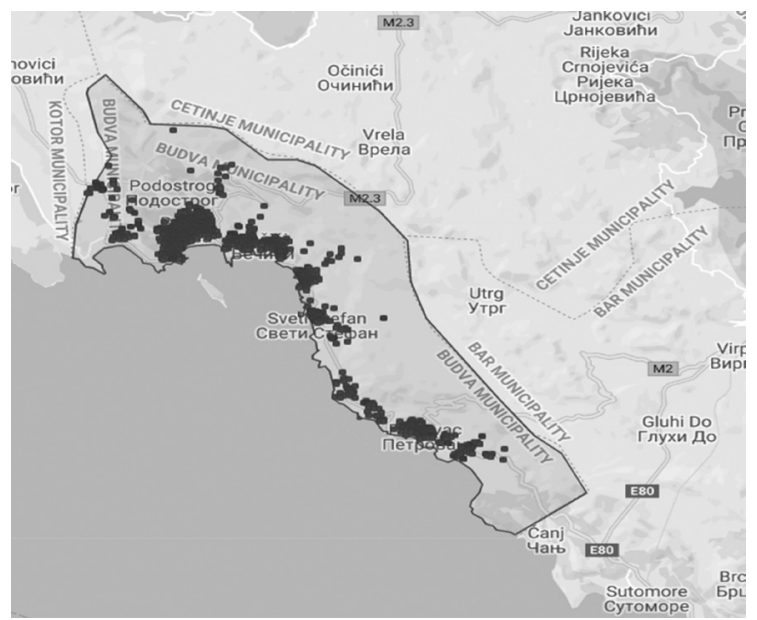

Figure 14. Spatial representation of accommodation unit distribution in the city area of Budva Source: retrieved from https://www.airdna.co/vacation-rental-data/app/me/default/budva/overview (2019, November 9)

In Podgorica are 707 active accommodation units that are registered at online tourism platforms, even $97 \%$ at the Airbnb platform. $82 \%$ is accommodation that is rented as entire place - illustrated in purple on the map (see Figure 13). 60\% make one room apartments. Average price per night is $€ 30$. Average occupancy is $43 \%$, or 156 days per year. Over $48 \%$ accommodation is rented up to 90 days annually. Average earnings made by such way of renting are $€ 306$ (2019, November 7 , retrieved from https://www.airdna.co/vacation-rental-data/app/me/default/podgorica/overview). 
In Budva are 7.668 active accommodation units that are registered at online tourism platforms, out of which $88 \%$ at the Airbnb platform. $86 \%$ is accommodation that is rented as entire place illustrated in purple on the map above (see Figure 14). Almost half make one room apartments or studios while multiple room apartments are scarce to find. Average price per night is €61. Since the coastal city is in question, the time in a year plays important role in the price building, e.g. whether summer months are considered or those out of season, prices vary, for instance: In October the price is merely $€ 43$, yet in August it is $€ 73$. More than $88 \%$ of properties are rented up to 90 days a year, i.e. mostly within the season, while some $11 \%$ even longer length of time.

Average earnings made by such renting is $€ 700$ per month (2019, November 9 , retrieved from https://www.airdna.co/vacation-rental-data/app/me/default/budva/overview).

Spatial distribution indicates that the biggest concentration of the available accommodation at the Airbnb platform are in the centre of Podgorica, in contrast to Budva, which has distributed properties to rent along the coastline, since the Tourism industry is essential in this area.

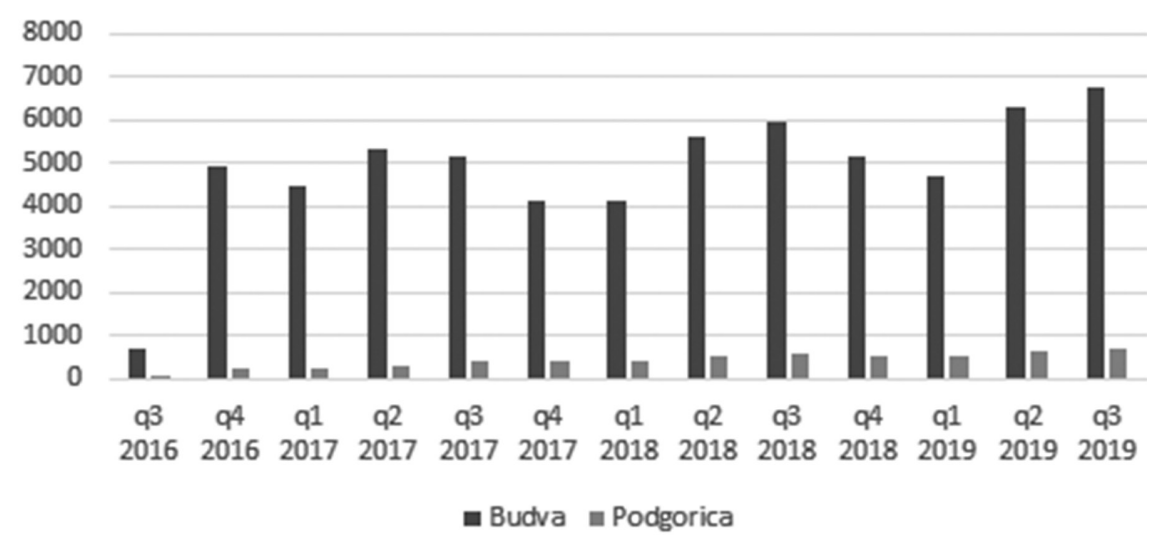

Figure 15. Illustration of the registered listings at the Airbnb platform in Podgorica and Budva by annual quarters in a period of 2016-2019

Sources: retrieved from

https://www.airdna.co/vacation-rental-data/app/me/default/podgorica/overview (2019, November 15), https://www.airdna.co/vacation-rental-data/app/me/default/budva/overview (2019, November 9)

In the graph is illustrated the growth of a number of listings over annual quarters. It is instantly clear that these two cities are not to be compared because of completely different aspects of tourism in question. What strikes most concerning available data for Budva, is a large increase in a number of registered listings after third quarter of 2016.

In Podgorica, this aspect of a tourism practice is still in its development stage.

\subsection{Northern Macedonia: Skopje and Ohrid}

According to available data (2019, November 11, retrieved from https://www.airdna.co/vacation-rental-data/app/mk/default/skopje/overview) and (2019, November 12, retrieved from https:// www.airdna.co/vacation-rental-data/app/mk/default/ohrid/overview) for the area of Northern Macedonia are chosen two cities to be analysed - Skopje and Ohrid. In Skopje are 1.824 active accommodation units that are registered at online tourism platforms, out of them, $95 \%$ are at the Airbnb application. $83 \%$ is accommodation that is rented as entire place- illustrated in purple on 
the map bellow (see Figure 16). 60\% are one room apartments. Average price per night is $€ 28$, occupancy $40 \%$, that is to say 146 days per year, average earnings are $€ 283$.

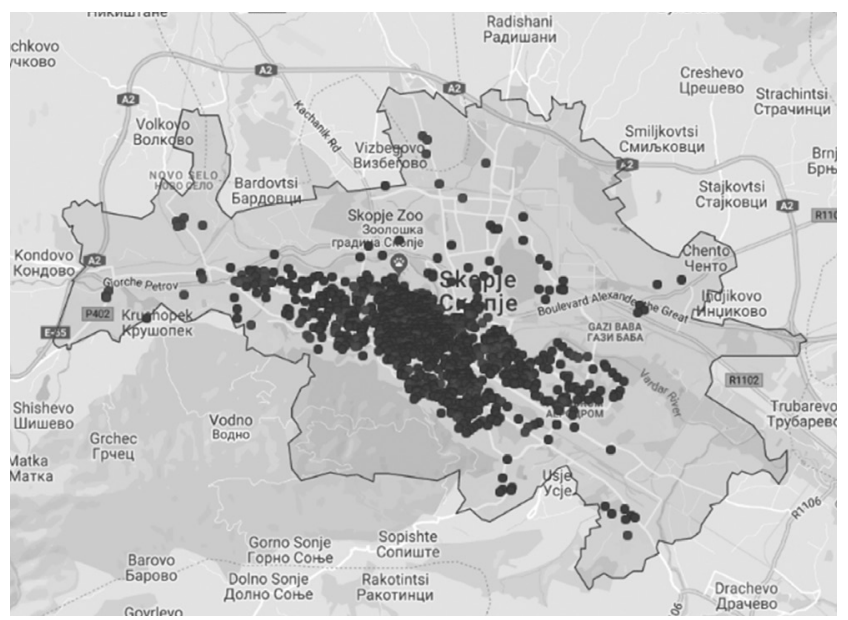

Figure 16. Spatial representation of accommodation unit distribution in the city area of Skopje Source: https:/www.airdna.co/vacation-rental-data/app/mk/default/skopje/overview (2019, November 11)

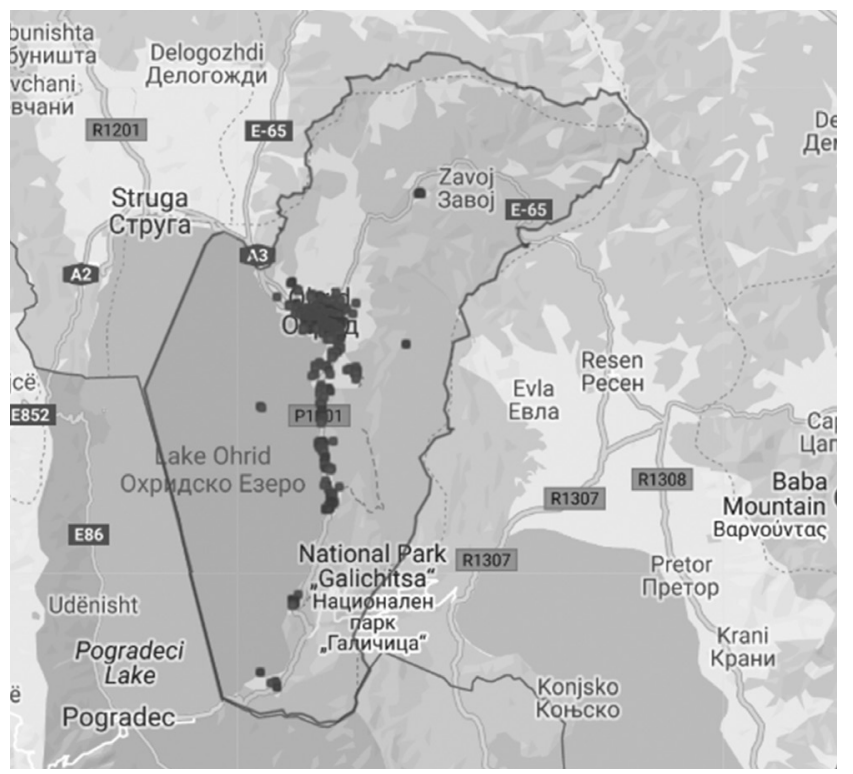

Figure 17. Spatial representation of accommodation unit distribution in the city area of Ohrid Source: https://www.airdna.co/vacation-rental-data/app/mk/default/ohrid/overview (2019, November 12)

In Ohrid are 1078 in total active accommodation units out of which 97\% at the Airbnb platform. $62 \%$ is accommodation that is rented as entire place via this application. Spatial representation in Figure 17 illustrates dominant position of the properties that are rented entirely, and more than a half account for one room apartments. Average price per night is $€ 33$, and monthly earnings are $€ 310$, with occupancy of 142 days a year, that is $39 \%$.

What is interesting about the regains of these two cities is extreme similarity of growth rates and the number of listings from 2016 till mid-2017. Significant growth is noticeable in the third quarter of 2017 as the maximum peak, or to say, the largest number of registered accommodation units, followed by a slight decrease marked in Skopje. 


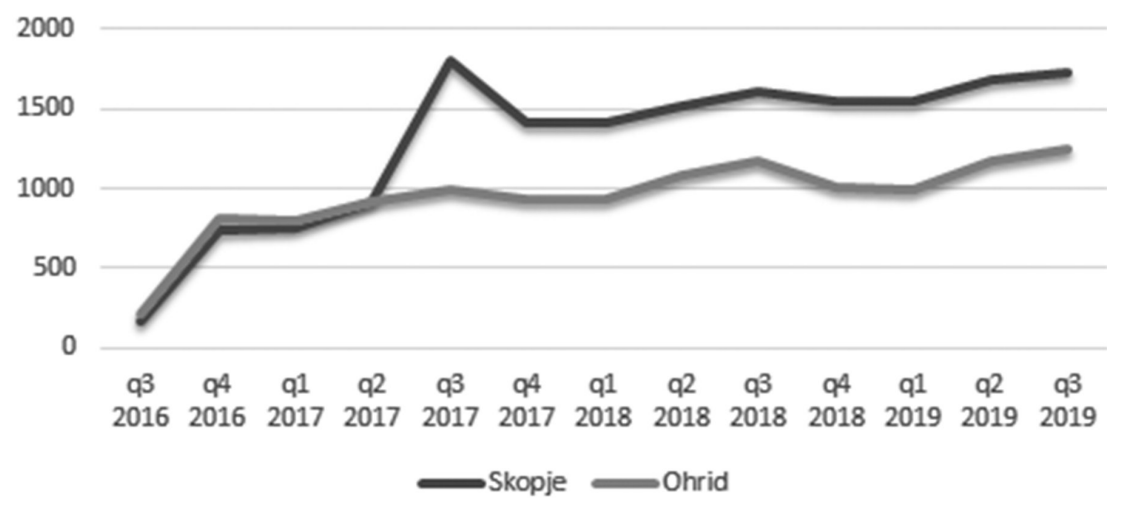

Figure 18. Illustration of the registered listings at the Airbnb platform in Skopje and Ohrid by annual quarters in a period of 2016-2019

Sources: retrieved from

https://www.airdna.co/vacation-rental-data/app/mk/default/skopje/overview (2019, November 15), https://www.airdna.co/vacation-rental-data/app/mk/default/ohrid/overview (2019, November 15)

Ohrid has no extreme increase yet, the research has shown that the number of listings is steadily growing over quarters, and that this way of booking accommodation to tourists becomes more and more popular each year.

\section{CONCLUSION}

After separate analysis of the available data for 12 cities in 6 countries, in order to come to conclusion on marketing influence of the Airbnb platform, it is necessary to do cross-sectional analysis that is completed in this part.

In Figure 19, is seen extent of the dominant influence of the Airbnb platform in comparison to other platforms of the same sort. Presented data is conclusive with the third quarter of 2019. The graph leads to conclusion that Budva has the largest number of registered listings. Interesting fact is that the second place according to a number of registered Airbnb accommodation units takes Belgrade ahead of other cities that are just tourist centres.

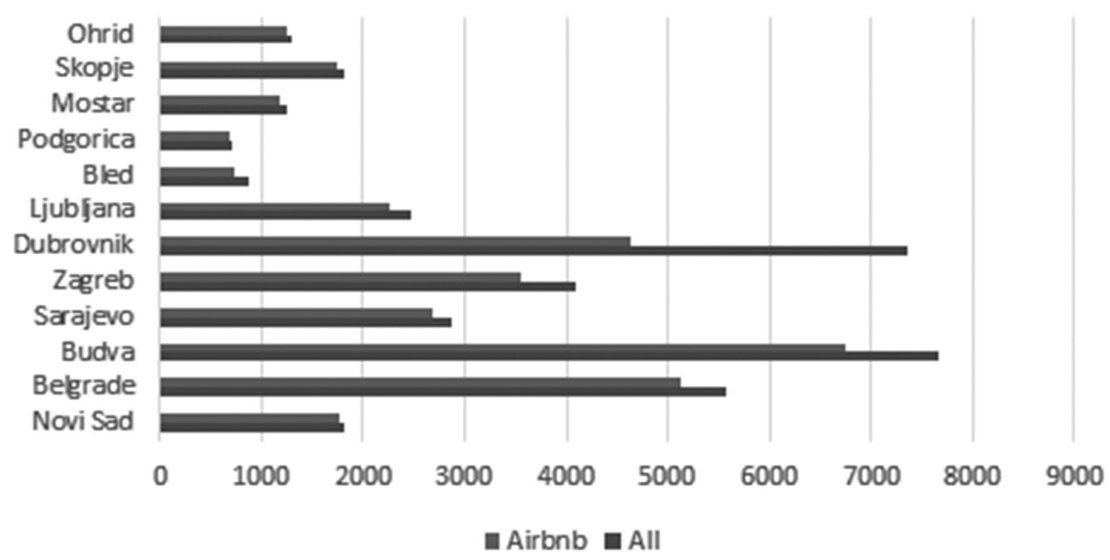

Figure 19. Illustration of total number of the online registered units at all platforms including the Airbnb platform in all analysed cities in a period of 2016-2019

Sources: retrieved from https://www.airdna.co/vacation-rental-data/app 
Table 2. Number of Airbnb accommodation units per capital cities

\begin{tabular}{|c|c|}
\hline Capital city & Number of Airbnb listings \\
\hline Ljubljana & 2250 \\
\hline Zagreb & 3559 \\
\hline Sarajevo & 2676 \\
\hline Belgrade & 5119 \\
\hline Podgorica & 686 \\
\hline Skopje & 1733 \\
\hline
\end{tabular}

Sources: retrieved from https://www.airdna.co/vacation-rental-data/app

Analysing data from the Table 2, Belgrade is a city with the most Airbnb registered accommodation units. Apart from registered accommodation units, in this work is analysed monthly income gained through renting apartments via this platform, taking also in consideration the average price per night and average occupancy in days.

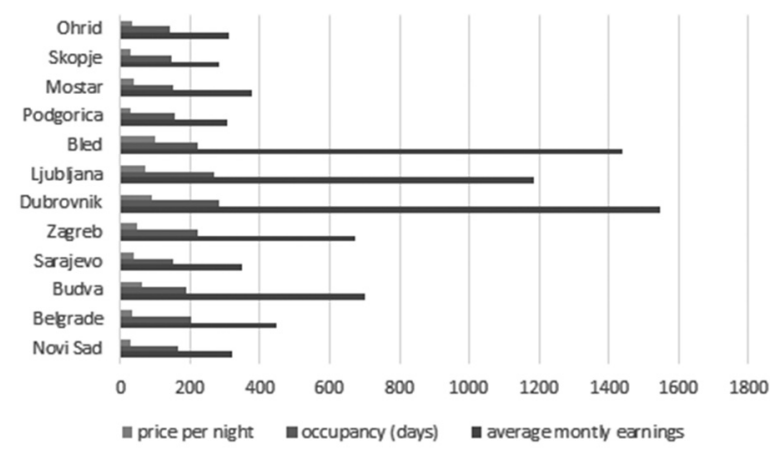

Figure 20. Analysis of average monthly earnings per a city

Sources: retrieved from https://www.airdna.co/vacation-rental-data/app

Observing prices per night, Bled has the biggest one of $€ 100$, and the highest average monthly income - Dubrovnik and Bled, $€ 1.549$ and $€ 1.437$ respectively, what is expected since that two extremely attractive tourist centres are in question.

The smallest price per night has Skopje with €28 and the least mean monthly income of 284 . The largest average occupancy has Dubrovnik with $77 \%$ and Ljubljana with $74 \%$, or to say: 281 and 270 days per year, while the fewest has Ohrid with 39\%, that is, 142 days per year.

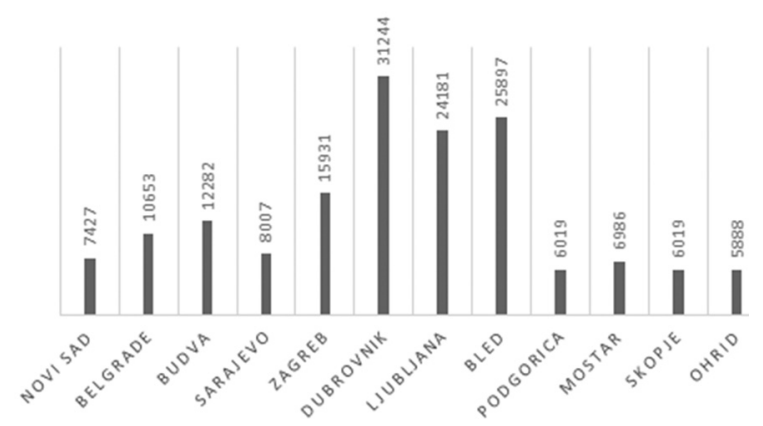

Figure 21. Estimated annual revenue in EUR

Sources: retrieved from https://www.airdna.co/vacation-rental-data/app

Figure 21, reveals that the Airbnb platform has high tendency of the growth in number of listings, and illustrates which of the cities are the locations that are most cost-effective in such tourism practice. 
Table 3. Estimated potential annual revenue in relation

to estimated price per night and occupancy in percentage and in days

\begin{tabular}{|l|c|c|c|c|}
\hline Town & Annual revenue & Average daily rate & Occupancy rate & Occupancy (days) \\
\hline Novi Sad & 7427 & 38 & $54 \%$ & 197 \\
\hline Belgrade & 10653 & 49 & $60 \%$ & 219 \\
\hline Budva & 12282 & 89 & $38 \%$ & 139 \\
\hline Sarajevo & 8007 & 38 & $58 \%$ & 212 \\
\hline Zagreb & 15931 & 77 & $57 \%$ & 208 \\
\hline Dubrovnik & 31244 & 140 & $61 \%$ & 223 \\
\hline Ljubljana & 24181 & 110 & $60 \%$ & 219 \\
\hline Bled & 25897 & 127 & $56 \%$ & 204 \\
\hline Podgorica & 6019 & 31 & $53 \%$ & 193 \\
\hline Mostar & 6986 & 43 & $45 \%$ & 164 \\
\hline Skopje & 6019 & 32 & $52 \%$ & 190 \\
\hline Ohrid & 5888 & 37 & $44 \%$ & 16 \\
\hline
\end{tabular}

\section{Data is retrieved from https://www.airdna.co/vacation-rental-data/app}

Based on available data can be done rough estimation, providing that to date tendency of increase in the number of registered listings at the Airbnb continues, in which region would be most cost effective letting a property via this application, under condition that it is in attractive location and of a capacity of 4 persons.

Apparently, the most would earn local population in Dubrovnik, then in Bled and Ljubljana with estimated annual earnings of $€ 31.244, € 25.897$ and $€ 24.181$ respectively, with occupancy around $60 \%$, that is, on average 221 days per year. With the same percentage of occupancy in Belgrade and Zagreb can be earned $€ 10.653$ and $€ 15.931$ annually. In the same potentially achievably price rank belongs Budva ( $€ 12.282)$ with average occupancy of barely $38 \%$ yearly, as it is expected, since Budva is primarily a summer resort. This estimation is calculated based on beforehand estimated price per night, which is reached relying on prices of nearby and most alike accommodation units according to location's attractiveness and capacity at the Airbnb platform.

General conclusion of the conducted research is seen in confirmation of the starting hypotheses on existence of significant marketing influence of applying the Airbnb platform in the real estate market at the Balkans as a tourism region that in the first place reflects through the increase in the number of on-line registered accommodation units a year after year, growth of the accommodation capacity, increased number of nights, increase of the length of a stay, growth of occupancy of accommodation capacity, growth of entrepreneurship of local population, current growth and potential increase of revenue, etc. Thus, based on everything analysed in this work, the conclusion is that as far as the Balkan goes, as a touristic region, of extreme significance is implementation of such modern on-line platforms like the Airbnb, since it leads to necessary effectiveness and efficiency in the harmonization of tourism offers - on one side and tourism demands - on other side. 


\section{REFERENCES}

Airbnb (2018), "Fast facts", Airbnb Press Room, retrieved from https://press.atairbnb.com/fast-facts/ (2018, August, 3)

Guttentag, D. (2015), "Airbnb: disruptive innovation and the rise of an informal tourism accommodation sector", Current Issues in Tourism, Vol. 18 No. 12, pp. 1192-1217.

Griswold, A. (2016), "It's time for hotels to really, truly worry about Airbnb”, Quartz, 12 July, retrieved from: https://qz.com/729878/its-time-for-hotels-to-really-truly-worry-about-airb$\mathrm{nb} /(2019$, October 10.)

Guttentag, D. and Smith, S. (2017), "Assessing Airbnb as a disruptive innovation relative to hotels: substitution and comparative performance expectations", International Journal of Hospitality Management, Vol. 64, pp. 1-10.

Hartmans, A. (2017), "Airbnb now has more listings worldwide than the top five hotel brands combined", Business Insider, 10 August, retrieved from:

www.businessinsider.com/airbnb-totalworldwide-listings-2017-8 (2018, August, 3)

Jøsang, A., Ismail, R. and Boyd, C. (2007), "A survey of trust and reputation systems for online service provision", Decision Support Systems, Vol. 43 No. 2, pp. 618-644.

Molla, R. (2017), "Airbnb is on track to rack up more than 100 million stays this year - and that's only the beginning of its threat to the hotel industry", Recode, 19 July, retrieved from: www.recode.net/2017/7/19/15949782/airbnb-100-million-stays-2017-threat-business-hotelindustry (2018, August, 3)

Quackenbush, C. (2018), "Airbnb apartment complexes could soon be coming to the US thanks to a \$200 million investment", Forbes, 9 January, retrieved from: http://fortune.com/2017/12/19/airbnbniido-branded-apartments-investment/ (2018, August, 3)

Radnović, Branislav; Simović, Vladimir; Petrović, Dragana (2019), “Internet Marketing Related Criminal Activities”, Monograph ,'Platforms for Digital Leadership, Faculty of Information Technology and Engineering, University Union-Nikola Tesla, Belgrade, Serbia, pp. 175-188.

Radnović, Branislav; Cvejić, Radoje; Brković, Milica (2019), "Phases of Development of Promotional Tourist Services Campaigns With Special Role of Digital Media”, Monograph,'Platforms for Digital Leadership, Faculty of Information Technology and Engineering, University Union-Nikola Tesla, Belgrade, Serbia, pp. 191-211.

Radnović, Branislav; Marić Radenko; Radnović, Vladana; Ilić, Milena, Lukač, Dragan (2015), "Marketing Research on Passenger Satisfaction With Public Transport Service in the city of Belgrade", International Scientific Journal Promet - Traffic and Transportation, Faculty of Transport and Traffic Sciences, University of Zagreb, Croatia, Vol. 27, no.1, pp. 47-57.

Team, T. (2018), "As a rare profitable unicorn, Airbnb appears to be worth at least \$38 billion", Forbes, 11 May, retrieved from:

Www.forbes.com/sites/greatspeculations/2018/05/11/as-a-rare-profitableunicorn-airbnbappears-to-be-worth-at-least-38-billion/\#7be4a4d72741 (2019, October 9).

Zervas, G., Proserpio, D. and Byers, J.W. (2017), "The rise of the sharing economy: estimating the impact of Airbnb on the hotel industry", Journal of Marketing Research, Vol. 54 No. 5, pp. 687-705.

https://press.airbnb.com/fast-facts/ (2019, October 9.)

https://www.airdna.co/vacation-rental-data/app/si/default/ljubljana/overview (2019, September 22) 
https://www.airdna.co/vacation-rental-data/app/si/default/bled/overview (2019, September 23)

https://www.airdna.co/vacation-rental-data/app/hr/default/zagreb/overview (2019, October 5)

https://www.airdna.co/vacation-rental-data/app/hr/default/dubrovnik/overview (2019, October 6)

https://www.airdna.co/vacation-rental-data/app/rs/default/belgrade/overview (2019, October 16)

https://www.airdna.co/vacation-rental-data/app/rs/default/novi-sad/overview (2019, October 17)

https://www.airdna.co/vacation-rental-data/app/ba/default/sarajevo/overview (2019, October 26)

https://www.airdna.co/vacation-rental-data/app/ba/default/mostar/overview (2019, October 27)

https://www.airdna.co/vacation-rental-data/app/me/default/podgorica/overview (2019, November 7)

https://www.airdna.co/vacation-rental-data/app/me/default/budva/overview (2019, November 9)

https://www.airdna.co/vacation-rental-data/app/mk/default/skopje/overview (2019, November 11)

https://www.airdna.co/vacation-rental-data/app/mk/default/ohrid/overview (2019, November 12) 